УдК 330.59

\title{
ДОХОДИ І ЯКІСТЬ ЖИТТЯ НАСЕЛЕННЯ УКРАЇНИ: СУЧАСНИЙ СТАН
}

\section{INCOMES AND QUALITY OF LIFE OF THE POPULATION OF UKRAINE: CURRENT STATUS}

\author{
Андрейцева Ірина Анатоліївна \\ кандидат економічних наук, доцент, \\ Кам'янець-Подільський національний університет імені Івана Огієнка \\ ORCID: https://orcid.org/0000-0003-0337-4107
}

\author{
Andreitseva Iryna \\ Kamianets-Podilskyi Ivan Ohiienko National University
}

\begin{abstract}
У статті узагальнено поняття «якість життя населення». Досліджено сучасний стан якості життя населення України. Проведено структурно-динамічний аналіз впливу доходів населення на якість життя. Виявлено переважання в структурі доходів населення двох джерел: соціальної допомоги і заробітної плати. Найвищі заробітки спостерігаються серед працівників фрінансової ссрери, промисловості, державного управління, інформації та телекомунікації. Встановлено значні диспропорції величини заробітків, зумовлені територіальними особливостями ринків праці. Виявлено існування гендерної нерівності щодо заробітних плат в країні. Серед населення країни виявлено значний відсоток жителів з середньодушовим доходом, нижчим прожиткового мінімуму. В сукупних витратах домогосподарств країни переважають витрати на харчування, оплату житла, комунальних послуг. Зроблено висновок про взаємозалежність якості трудового потенціалу і якості життя населення України.

Ключові слова: якість життя населення, доходи населення, номінальна заробітна плата, гендерна нерівність, сукупні витрати домогосподарств, грошові доходи домогосподарств, споживання продуктів харчування.
\end{abstract}

В статье обобщено понятие «качество жизни населения». Исследовано современное состояние качества жизни населения Украины. Проведен структурно-динамический анализ влияния доходов населения на качество жизни. Выявлено преобладание в структуре доходов населения двух источников: социальной помощи и заработной платы. Самые высокие заработки наблюдаются среди работников фринансовой сферы, промышленности, государственного управления, инорормации и телекоммуникации. Установлены значительные диспропорции величины заработков, обусловленные территориальными особенностями рынков труда. Обнаружено существование гендерного неравенства относительно заработных плат в стране. Среди населения страны выявлен значительный процент жителей с среднедушевым доходом, ниже прожиточного минимума. В совокупных расходах домохозяйств страны преобладают расходы на питание, оплату жилья, коммунальных услуг. Сделан вывод о взаимозависимости качества трудового потенциала и качества жизни населения Украины.

Ключевые слова: качество жизни населения, доходы населения, номинальная заработная плата, гендерное неравенство, совокупные расходы домохозяйств, денежные доходы домохозяйств, потребление продуктов питания.

The progressive development of the country depends on the quality of life of the population, so the issue of income generation is relevant in an unstable economy. Improving the quality of life of the population of Ukraine is an important socio-economic prerequisite for the development of its labor potential, which is determined by the level of satisfaction of the needs of the population and characterizes the qualitative and quantitative aspects of reproduction of labor potential. Thus, other things being equal, in regions with a low standard of living, focused on the worker with the least developed consumption, there is a reduced level of education, life expectancy, productivity and quality of work. The purpose of the article is to analyze the quality of life of the population of Ukraine, study the income of citizens and assess the satisfaction of needs to maintain a proper standard of living. The methodological and informational basis of the study are the articles of scientists who cover the issues of statistical assessment of income, quality of life, materials of periodicals, Internet resources on these issues. During the study, methods of systematic and logical analysis, the method of generalization of information, comparative analysis, structural and dynamic analysis were used, as well as the method of visualization of information using graphs and tables. The article summarizes the concept of "quality of life". The current state of quality of life of the population of Ukraine is studied. A structural and dynamic analysis of the impact of household incomes on quality of life has been conducted. The predominance in 
the structure of household income of two sources: social assistance and wages. The highest earnings are observed among employees of the financial sector, industry, government, information and telecommunications. Significant disparities in the amount of earnings due to the territorial features of labor markets have been established. The existence of gender inequality in terms of wages in the country has been revealed. Among the population of the country found a significant percentage of residents with per capita income below the subsistence level. The total expenditures of households in the country are dominated by expenditures on food, housing, utilities. The study gives grounds to assert the interdependence of the quality of labor potential and quality of life of the population of Ukraine, namely: on the one hand, improving the quality of human resources is possible provided improved education, health, housing, working conditions, in other words, by improving quality of life in society; on the other hand, the quality of life depends entirely on the quality of the labor potential of employees.

Keywords: quality of life, household incomes, nominal wages, gender inequality, total household expenditures, household monetary incomes, food consumption.

Постановка проблеми. Прогресивний розвиток країни залежить від якості життя населення, тому питання орормування доходів населення є актуальним за умов нестабільної економіки. Підвищення якості життя населення України $€$ важливою соціально-економічною передумовою розвитку його трудового потенціалу, яке визначається рівнем задоволення потреб населення і характеризує якісні й кількісні сторони відтворення трудового потенціалу. Так, за інших рівних умов у регіонах 3 низьким рівнем життя, орієнтованих на працівника 3 мінімально розвинутим споживанням, спостерігається знижений рівень освіти, тривалості життя, продуктивності та якості праці.

Аналіз останніх досліджень і публікацій. Дослідженню доходів та якості життя населення присвячені праці В.М. Гейця, О.А. Грішнової, Е.М. Лібанової, В.О. Мандибури, В.М. Новікова, Л.С. Шевченко та інших.

Виділення невирішених раніше частин загальної проблеми. Дослідженням доходів й якості життя населення займалось багато науковців проте врахування сучасної економічної ситуації зумовлює необхідність подальших досліджень.

Постановка завдання. Метою статті $\epsilon$ аналіз якості життя населення України, дослідження доходів громадян та оцінка задоволеності потреб для підтримання на належному рівні життєдіяльності.

Виклад основного матеріалу дослідження. Якість життя населення - ступінь задоволення різноманітних потреб населення за певний проміжок часу в суспільстві. За визначенням Всесвітньої організації охорони здоров'я - це сприйняття людьми свого становища в житті залежно від культурних особливостей, системи цінностей, згідно з їх очікуваннями, цілями, стандартами.

Категорія «якість життя» $€$ ширшою, ніж лише матеріальна забезпеченість. Вона трактується як система показників, що визначають ступінь реалізації життєвих планів людей, задоволення їхніх потреб.
Важливим показником вимірювання якості життя $€$ доходи населення. Джерелами фрормування доходів домогосподарств в Україні виступають: заробітна плата, пенсії, стипендії, субсидії, соціальні допомоги, доходи від підсобного господарства, доходи від підприємницької діяльності і самозайнятості, доходи від власності, інші доходи (спадок, аліменти, гонорари тощо) [1].

Проаналізуємо життєвий рівень населення України.

Структура доходів населення за 2015-2020 роки свідчать про переважання у ній двох найбільш значимих джерел: заробітної плати $(45,9 \%$ в 2020 р.), соціальної допомоги та інших трансрертів (33,6\%). Найменшу частку в доходах займають доходи від власності лише 2,6\%. Щодо джерела прибутку та змішаного доходу його питома вага 17,9\%. Динаміка доходів за останні роки демонструє сталу тенденцію до зниження часток доходу від власності 3 4,5 до 2,6\% та прибутку 3 18,2 до 17,9\%, що є негативним явищем щодо диверсифрікації джерел доходів.

Розглянемо відмінності у рівнях заробітної плати в залежності від сорери діяльності.

Дані таблиці вказують на суттєве зростання середньомісячної номінальної заробітної плати працівників за видами економічної діяльності, зокрема, в 2020 році вона зросла в 2,8 разів за 6 років дослідження. Найвищі заробітки в країні притаманні працівникам фрінансової та страхової ссрери (20379 грн.), інфрормації та телекомунікації (19888 грн.), наукової, технічної діяльності (16613 грн.), державного управління, оборони (16443 грн.) та промисловості (12759 грн.). Найнижча зарплата у працівників освітньої галузі (9271 грн.) та охорони здоров'я, соціальної допомоги (8848 грн.). Динаміка заробітних плат за видами економічної діяльності загалом стала, окремі зрушення мають місце щодо ссрери транспорту, оплата раці зросла з 4556 до 11597, або на 154,5\%, у працівників сільського господарства - зросла на 6594 грн. за останніх 6 років, середні доходи 


\begin{tabular}{|c|c|c|c|c|c|c|}
\hline \multirow[t]{2}{*}{ 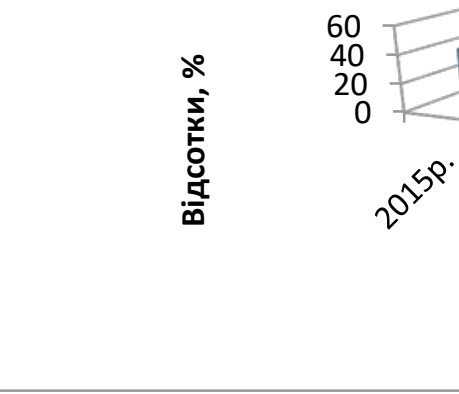 } & \multicolumn{2}{|r|}{$2^{0^{80^{\circ}}}$} & \multicolumn{2}{|c|}{$v^{p^{p}}$} & & \\
\hline & $2015 \mathrm{p}$. & 2016 p. & 2017 p. & $2018 p$. & 2019 p. & 2020 p. \\
\hline - зарплата & 40 & 43,8 & 45,6 & 47,1 & 47 & 45,9 \\
\hline прибуток та змішаний дохід & 18,2 & 18,4 & 18 & 17,6 & 18,1 & 17,9 \\
\hline дохід від власності & 4,5 & 3,7 & 3 & 2,8 & 3,1 & 2,6 \\
\hline $\begin{array}{l}\text { соціальні допомоги та } \\
\text { інші трансферти }\end{array}$ & 37,3 & 34,1 & 33,4 & 32,5 & 31,8 & 33,6 \\
\hline
\end{tabular}

Рис. 1. Структура доходів населення України за 2015-2020 роки

Джерело: побудовано за [2]

характерні для представників галузі мистецтва, спорту (9624 грн.).

Існують значні диспропорції величини заробітків, пов'язані з територіальними особливостями ринків праці.

Так, високі заробітні плати притаманні для жителів Донецької (11716 грн.), Київської (11003 грн.), Дніпропетровської (10751 грн.), Запорізької областей (10480 грн.), які належать до промислових, фрінансових центрів. Середні рівні оплати праці спостерігаються в Миколаївській (9976 грн.), Полтавській (9846 грн.), Львівській (9271грн.), Одеській областях (9246 грн.). І традиційно найменші заробітніплати -ужителів Терно- пільського (8275 грн.), Чернігівського (8206 грн.), Херсонського (8187 грн.),Чернівецького регіонів (8066 грн.), що зумовлено регіональними особливостями ринків праці. Ця ситуація мала місце й 5 років тому, хоча варто відзначити покращення ситуації у населення Вінницького, Хмельницького регіонів. Дана тенденція пояснюється галузевими відмінностями у рівнях зарплат і відповідно спеціалізацією окремих територій.

Аналіз статистичних даних рис. 2 вказує на існування гендерної нерівності щодо заробітної плати в Україні загалом. Зокрема, найменша відмінність у заробітках присутня в освітній сорері (96,2\% - 2019 р.), державного управління

\section{Середньомісячна номінальна заробітна плата працівників України за видами економічної діяльності за 2015-2020 роки, грн.}

\begin{tabular}{|l|c|c|c|c|c|c|}
\hline \multicolumn{1}{|c|}{ Види економічної діяльності } & $\mathbf{2 0 1 5}$ р. & $\mathbf{2 0 1 6}$ р. & $\mathbf{2 0 1 7}$ p. & $\mathbf{2 0 1 8}$ p. & $\mathbf{2 0 1 9}$ р. & $\mathbf{2 0 2 0}$ р. \\
\hline Усього & $\mathbf{4 1 9 5}$ & $\mathbf{5 1 8 3}$ & $\mathbf{7 1 0 4}$ & $\mathbf{8 8 6 5}$ & $\mathbf{1 0 4 9 7}$ & $\mathbf{1 1 5 9 1}$ \\
\hline Сільське господарство & 3140 & 3916 & 5761 & 7166 & 8738 & 9734 \\
\hline Промисловість & 4789 & 5902 & 7631 & 9633 & 11788 & 12759 \\
\hline Будівництво & 3551 & 4731 & 6251 & 7845 & 9356 & 9328 \\
\hline Торгівля, ремонт автомобілів & 4692 & 5808 & 7631 & 9404 & 10795 & 10985 \\
\hline Транспорт & 4556 & 5776 & 7883 & 10010 & 11754 & 11597 \\
\hline Інформація та телекомунікації & 7111 & 9530 & 12018 & 14276 & 17543 & 19888 \\
\hline Фінансова та страхова діяльність & 8603 & 10227 & 12865 & 16161 & 19132 & 20379 \\
\hline Наукова, технічна діяльність & 6736 & 8060 & 10039 & 12144 & 14550 & 16613 \\
\hline Державне управління, оборона & 4381 & 5953 & 9372 & 12698 & 14785 & 16443 \\
\hline Освіта & 3132 & 3769 & 5857 & 7041 & 8135 & 9271 \\
\hline Охорона здоров'я, соціальна допомога & 2829 & 3400 & 4977 & 5853 & 7020 & 8848 \\
\hline Мистецтво, спорт, розваги & 4134 & 4844 & 6608 & 7612 & 8659 & 9624 \\
\hline
\end{tabular}




\section{Середньомісячна номінальна заробітна плата працівників}

Таблиця 2 за регіонами України за 2015-2019 роки, грн.

\begin{tabular}{|l|c|c|c|c|c|}
\hline & $\mathbf{2 0 1 5} \mathbf{p .}$ & $\mathbf{2 0 1 6} \mathbf{p .}$ & $\mathbf{2 0 1 7} \mathbf{p .}$ & $\mathbf{2 0 1 8} \mathbf{p .}$ & $\mathbf{2 0 1 9} \mathbf{p .}$ \\
\hline Вінницька & 3396 & 4189 & 6121 & 7801 & 9299 \\
\hline Волинська & 3291 & 4047 & 5849 & 7324 & 8663 \\
\hline Дніпропетровська & 4366 & 5075 & 6939 & 8862 & 10751 \\
\hline Донецька & 4980 & 5989 & 7764 & 9686 & 11716 \\
\hline Житомирська & 3271 & 4000 & 5836 & 7372 & 8528 \\
\hline Запорізька & 4200 & 5080 & 6863 & 8726 & 10480 \\
\hline Закарпатська & 3381 & 4291 & 6355 & 8070 & 9202 \\
\hline вано-Франківська & 3402 & 4202 & 6074 & 7551 & 8817 \\
\hline Київська & 4153 & 5229 & 7188 & 9097 & 11003 \\
\hline Кіровоградська & 3282 & 3974 & 5792 & 7191 & 8360 \\
\hline Луганська & 3427 & 4637 & 5862 & 7365 & 8731 \\
\hline Львівська & 3646 & 4559 & 6391 & 8001 & 9271 \\
\hline Миколаївська & 3984 & 4887 & 6709 & 8160 & 9976 \\
\hline Одеська & 3897 & 4809 & 6542 & 8011 & 9246 \\
\hline Полтавська & 3783 & 4621 & 6551 & 8375 & 9846 \\
\hline Рівненська & 3573 & 4364 & 6013 & 7469 & 8967 \\
\hline Сумська & 3449 & 4131 & 5946 & 7324 & 8579 \\
\hline Тернопільська & 2994 & 3695 & 5554 & 6969 & 8275 \\
\hline Харківська & 3697 & 4448 & 6244 & 7657 & 9081 \\
\hline Херсонська & 3123 & 4046 & 5842 & 7058 & 8187 \\
\hline Хмельницька & 3371 & 4043 & 5938 & 7346 & 8672 \\
\hline Черкаська & 3360 & 4148 & 6042 & 7478 & 8838 \\
\hline Чернівецька & 3050 & 3828 & 5621 & 6991 & 8066 \\
\hline Чернігівська & 3295 & 4002 & 5636 & 6995 & 8206 \\
\hline
\end{tabular}

Джерело: складено за [2]

(95,5\%), охорони здоров'я (89,3\%). Протилежна ситуація - у галузі адміністративного обслуговування, заробітна плата жінок на 4 \% перевищує чоловічу, динаміка до зростання простежується за останні роки. Найбільш відчутна різниця у рівнях оплати праці у працівників фрінансової ссрери (63,9\%), мистецтва, спорту (64,1\%), промисловості $(74,2 \%)$. У середньому по країні спостерігається динаміка зростання гендерної нерівності щодо заробітних плат в 2019 році на 2,3\% порівняно з 2015 роком.

Дані рис. 3 дозволяють узагальнити, що серед населення України існує значний відсоток жителів із середньодушовими доходами, нижчими прожиткового мінімуму. Зокрема, у 2015 році частка такого населення складала $62,6 \%$, у 2019 році - 29,9\%. Отже, статистичні дані вказують на зниження даного параметру, тобто покращення ситуації.

Дослідження сукупних витрат домогосподарств країни характеризує основні напрями використання їх ресурсів. Найбільшу питому вагу займають споживчі сукупні витрати -
93\%. Зокрема, 58\% - продовольчі товари, $25 \%$ - непродовольчі товари і послуги, оплата житла і комунальних послуг - 10\%.

Сукупні витрати домогосподарств України в 2019 році дещо змінились щодо їх структури в 2015 році. Зокрема, зменшилась величина продовольчих товарів на 6\% та зросли частки непродовольчих товарів на 1\%, оплата житла і комунальних послуг на 3\%.

Ці параметри свідчать про погіршення життєвого рівня населення країни, оскільки найбільша питома вага витрат припадає на харчування й оплату житла і комунальні послуги.

Проаналізуємо основні статті споживчих витрат населення України.

Аналіз таблиці 3 дозволяє підсумувати інфрормацію про структуру витрат домогосподарств за основними статтями споживчих витрат за п'ятирічний період. Зокрема, їх загальна величина зросла на 95,3\% і становила у звітному році 9670,2 грн. Структура витрат зазнала певних трансорормацій в 2019 році. Найбільшу частку традиційно займають про- 


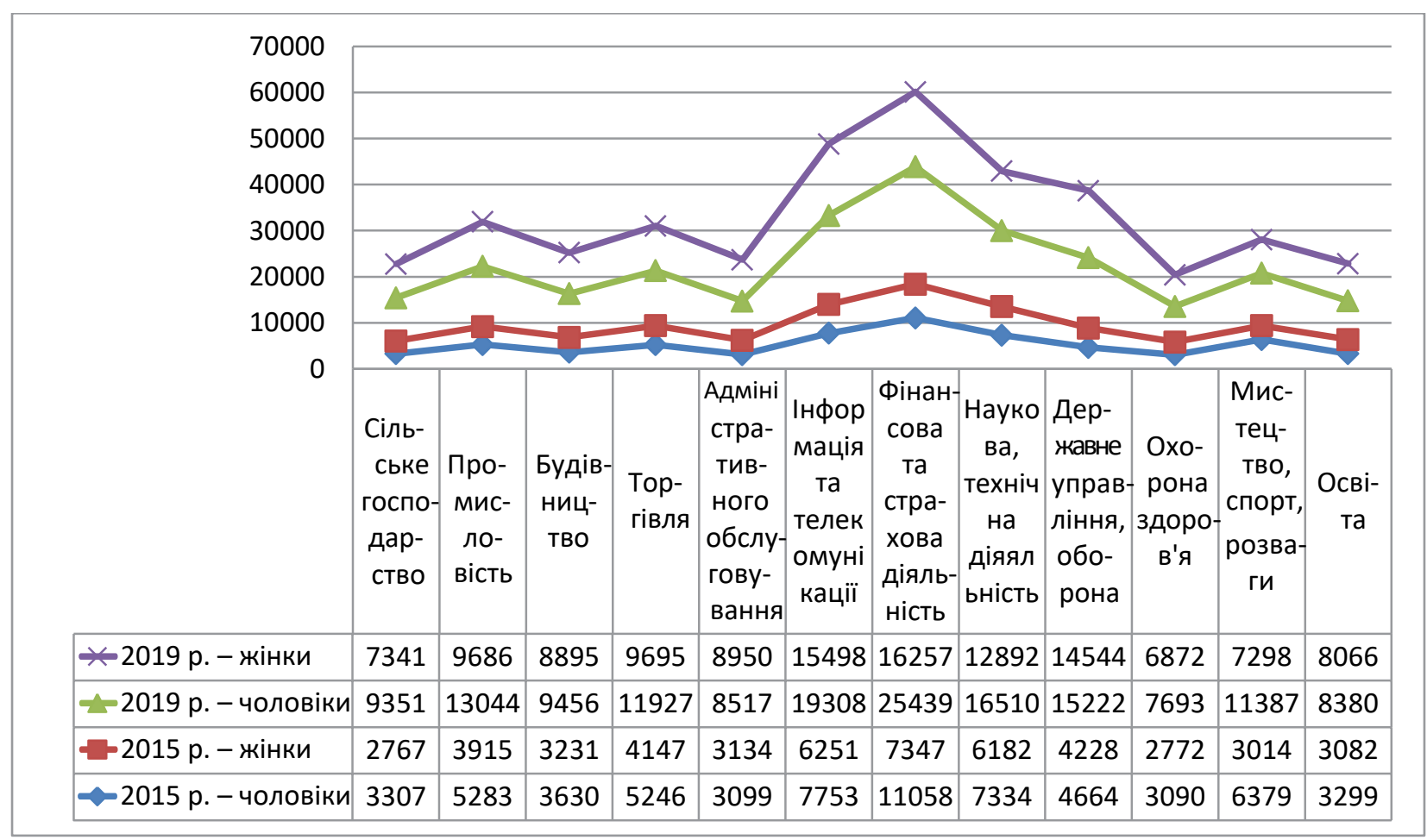

Рис. 2. Номінальна заробітна плата працівників за статтю, за видами економічної діяльності України за 2015-2019 роки, грн.

Джерело: складено за [2]

дукти харчування та безалкогольні напої 46,6\%, що на $6,5 \%$ менше рівня 2015року; частка одягу і взуття скоротилась на 0,2\% і сягнула величини 5,5\%; зросла частка витрат на комунальні послуги на 2,9\% (14,6\%), витрат на охорону здоров'я на $0,4 \%(4,1 \%)$ та транспорт на $1,1 \%$
(4,8\%). Витрати на освіту не змінились і сягнули рівня 1,1\%, що є свідченням зниження життєвого рівня населення, оскільки більша питома вага витрат припадає на харчування, одяг і комунальні послуги. I як наслідок дещо скоротились витрати на алкогольні напої (на 0,1\%).

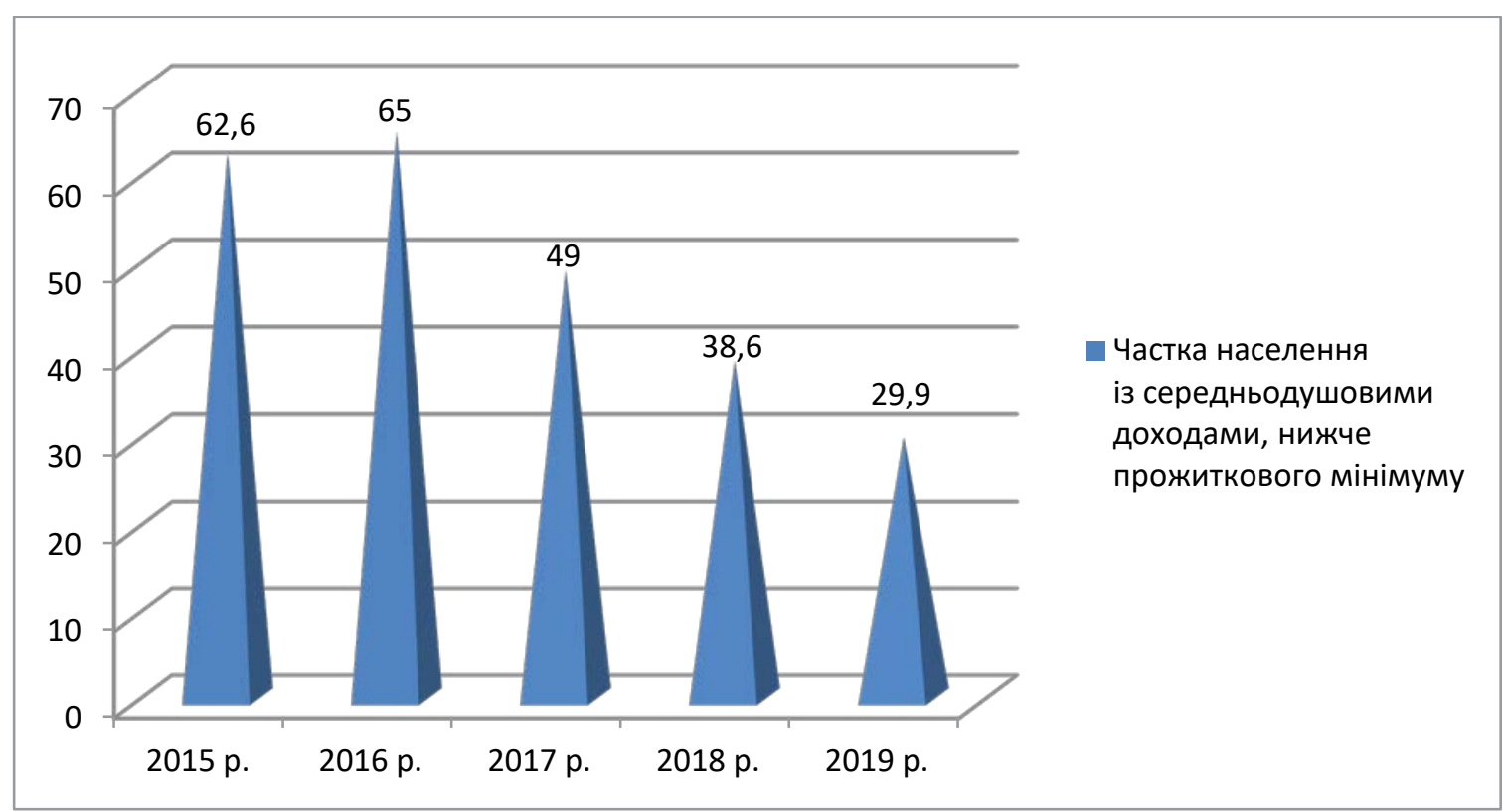

Рис. 3. Динаміка часток населення України із середньодушовими доходами за місяць, нижче фрактичного прожиткового мінімуму, \% 


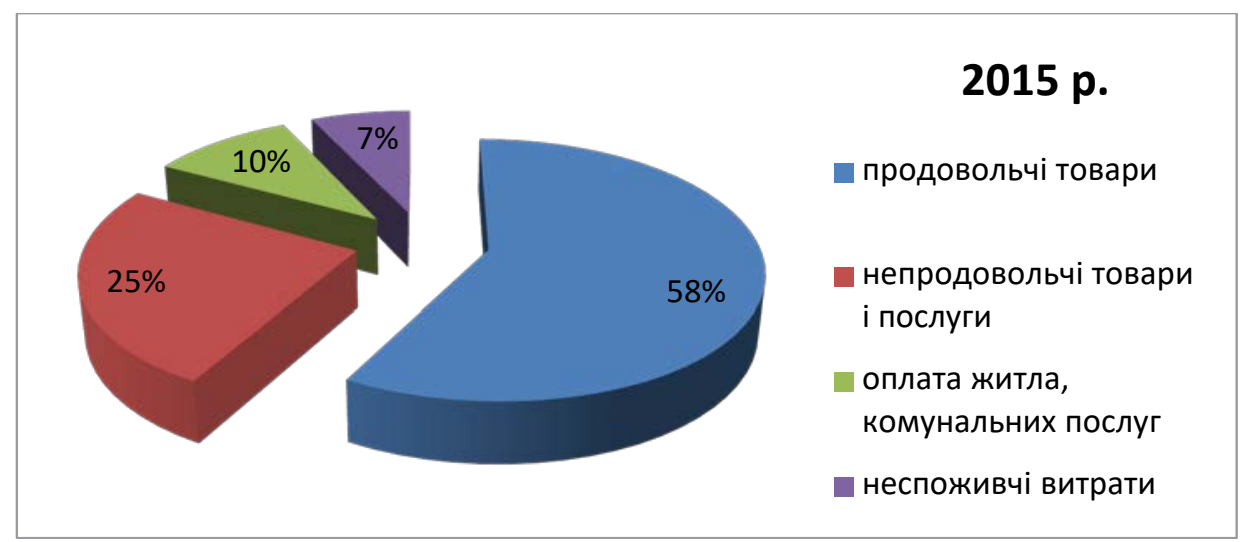

Рис. 4. Структура сукупних витрат домогосподарств України за 2015 рік, \% Джерело: складено за [2]

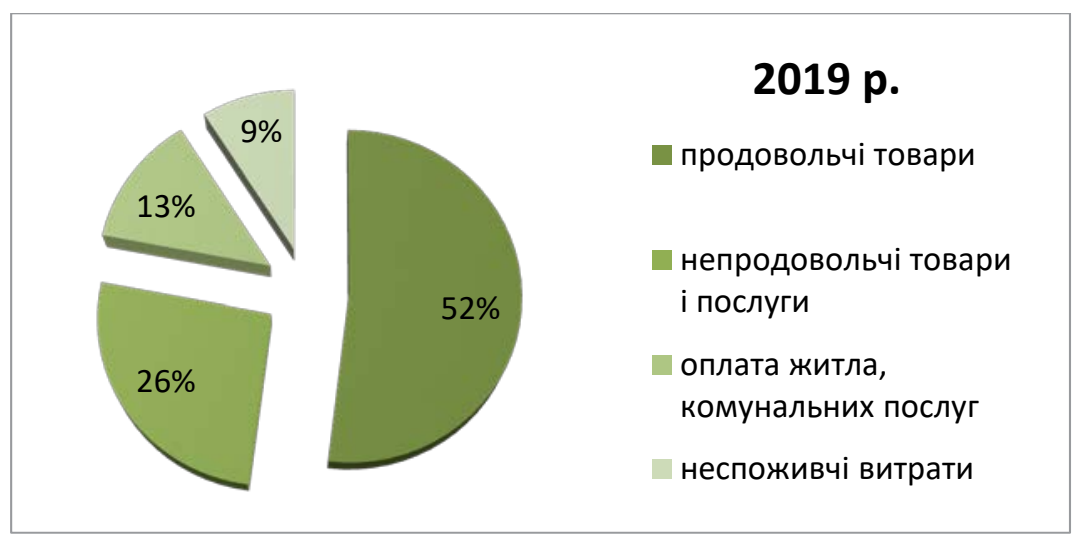

Рис. 5. Структура сукупних витрат домогосподарств України за 2019 рік, \%

Джерело: складено за [2]

Таблиця 3

Структура витрат домогосподарств України за основними статтями споживчих витрат за 2015-2019 роки

\begin{tabular}{|c|c|c|c|c|c|}
\hline $\begin{array}{c}\text { Статті споживчих } \\
\text { витрат }\end{array}$ & 2015 p. & 2016 p. & 2017 p. & 2018 p. & 2019 p. \\
\hline Усього витрат, грн. & 4952 & 5720.4 & 7139.4 & 8308.6 & 9670.2 \\
\hline Споживчі витрати, \%: & 92.9 & 93.2 & 92.9 & 92 & 91.3 \\
\hline продукти харчування & 53.1 & 49.8 & 47.9 & 47.7 & 46.6 \\
\hline алкогольні напої & 1.3 & 1.1 & 1.1 & 1.3 & 1.2 \\
\hline тютюнові вироби & 2 & 1.8 & 2 & 2.1 & 2 \\
\hline одяг і взуття & 5.7 & 5.6 & 5.5 & 5.4 & 5.5 \\
\hline комунальні послуги & 11.7 & 16 & 17 & 15.2 & 14.6 \\
\hline утримання житла & 2 & 1.7 & 2 & 2.1 & 1.8 \\
\hline охорона здоров'я & 3.7 & 4.2 & 3.8 & 4 & 4.1 \\
\hline транспорт & 3.7 & 3.6 & 3.7 & 3.7 & 4.8 \\
\hline ЗВ'язоК & 2.4 & 2.3 & 2.4 & 2.6 & 2.8 \\
\hline відпочинок і культура & 1.5 & 1.4 & 1.6 & 1.8 & 1.6 \\
\hline освіта & 1.1 & 1 & 1.1 & 1 & 1.1 \\
\hline ресторани, готелі & 2 & 2.2 & 2.3 & 2.4 & 2.6 \\
\hline різні товари та послуги & 2.7 & 2.5 & 2.5 & 2.7 & 2.6 \\
\hline
\end{tabular}

Джерело: складено за [2] 


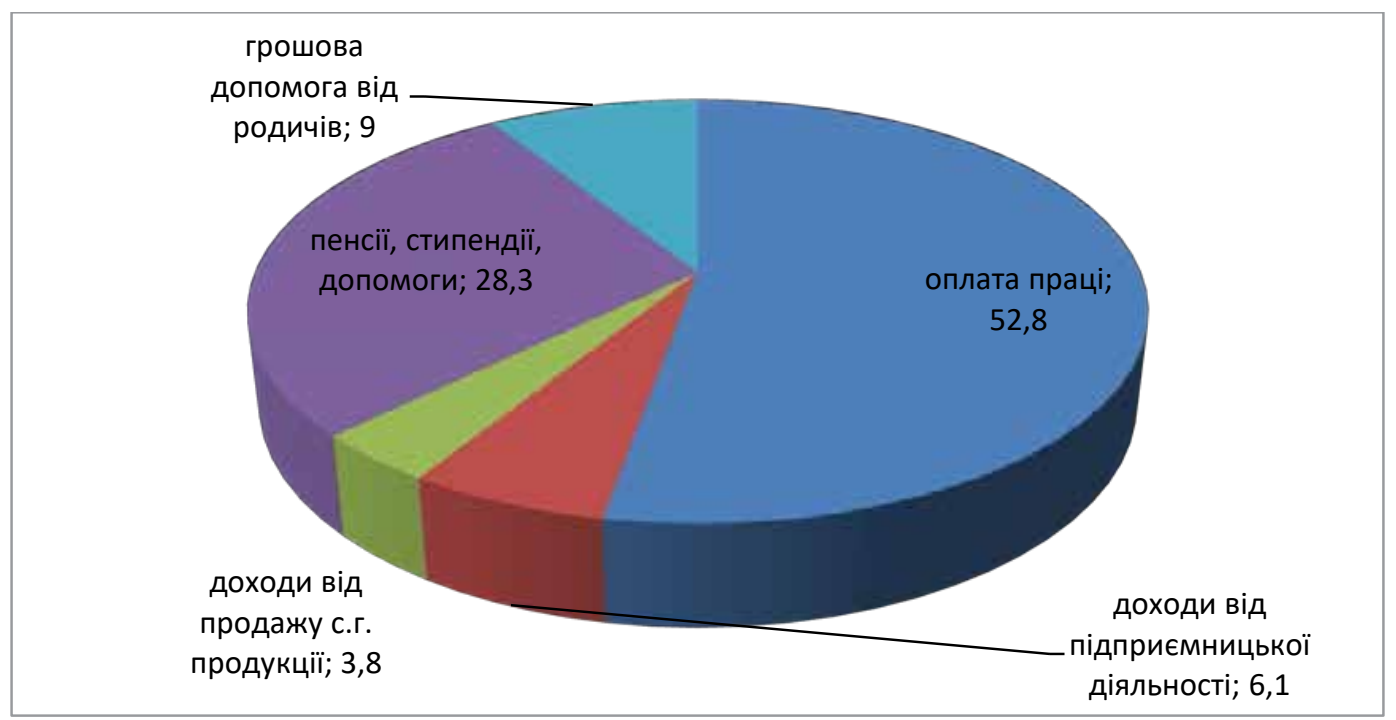

Рис. 6. Структура грошових доходів домогосподарств України за 2015 рік Джерело: побудовано за [2]

Витрати на відпочинок і культуру незначні лише 1,6\%, що підтверджує тезу про низький рівень життя населення країни.

Отже, можназробити висновок, левова частка витрат здійснюється на, власне, відтворення трудового потенціалу і зовсім мізерна на інвестиції у людський капітал, що знижує перспективи у майбутньому покращення якісних характеристик трудового потенціалу суспільства.

Розглянемо джерела фрормування грошових доходів домогосподарств України рис. 6). Грошові доходи домогосподарств за 2015 рік фрормуються переважно за рахунок оплати праці (52,8\%), бюджетних трансфрертів (пенсій, стипендій, допомоги - 28,3\%), грошової допомоги від родичів (9\%). Частки доходів від ведення підприємницької діяльності (6,1\%) і від продажу сільськогосподарської продукції $(3,8 \%)$ незначні.

За досліджуваний період відбулись певні зрушення у структурі грошових доходів домогосподарств країни: зросла частка оплати праці на 13,1\%, доходів від підприємницької діяльності на 1,6\%. Проте скоротилась питома вага грошової допомоги від родичів на 2,7\%, бюджетних транссрертів на 8,5\% і доходів від продажу сільськогосподарської продукції на 3,5\%.

Проведемо дослідження споживання продуктів харчування на 1 особу в домогосподарствах України, з огляду на те, що їх питома вага сягає понад 46\% усіх споживчих витрат.

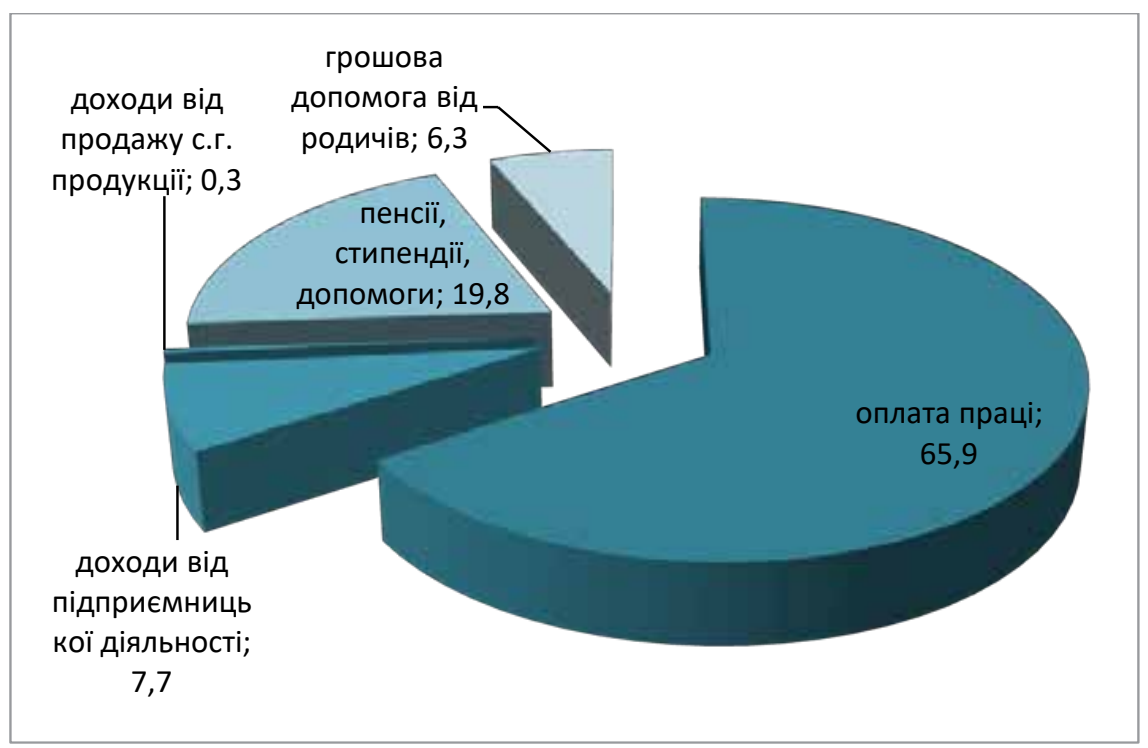

Рис. 7. Структура грошових доходів домогосподарств України за 2019 рік Джерело: побудовано за [2] 
Динаміка споживання продуктів харчування в домогосподарствах України за місяць, кг на 1 особу

\begin{tabular}{|l|c|c|c|}
\hline \multicolumn{1}{|c|}{ Продукти харчування } & $\mathbf{2 0 1 5} \mathbf{~ p . ~}$ & $\mathbf{2 0 1 8} \mathbf{~ . ~}$ & $\mathbf{2 0 1 9} \mathbf{~}$. \\
\hline м'ясо і м'ясопродукти & 4.6 & 4.9 & 5.1 \\
\hline молоко і молочні продукти & 19.8 & 19 & 19 \\
\hline яйця, шт. & 19 & 18 & 20 \\
\hline риба і рибопродукти & 1.2 & 1.4 & 1.5 \\
\hline цукор & 2.8 & 2.7 & 2.6 \\
\hline олія та інші рослинні жири & 1.6 & 1.5 & 6.4 \\
\hline картопля & 6.6 & 6.3 & 8.8 \\
\hline овочі та баштанні & 8.8 & 8.9 & 4.4 \\
\hline фрукти, ягоди & 3.1 & 3.8 & 8.1 \\
\hline хліб і хлібні продукти & 8.5 & 8.3 & \\
\hline
\end{tabular}

Джерело: складено за [2]

Дані таблиці 4 свідчать про традиційне переважання серед продуктів харчування українського населення хлібних продуктів (8,1 кг у 2019 р.), овочів (8,8 кг), картоплі (6,2 кг), яєць (20 шт.) та молочних продуктів (19 кг). Незначна частка припадає на м'ясо (5,1 кг), рибу (1,5 кг) та фррукти і ягоди (4,4 кг). Динаміка споживання свідчить про незначне покращення в раціоні харчування домогосподарств за досліджуваний період, оскільки зросло споживання м'яса на 0,5 кг, риби на 0,3 кг, яєць на 1 шт., фрруктів і ягід на 1,3 кг.

Отже, можна зробити висновок, що населення країни щодо продуктів харчування надає перевагу більш дешевшим і калорійним продуктам 3 огляду на невисокий рівень доходів населення.

Висновки. За результатами дослідження виявлено, що в структурі доходів населення переважають два найбільш значимих джерела: соціальні допомоги та інші трансорерти $(33,6 \%)$, заробітна плата $(45,9 \%)$. Найвищі заробітки характерні для працівників фрінансової сорери, промисловості, державного управління, інфрормації та телекомунікації, наукової, технічної діяльності. Існують значні диспропорції величини заробітків, пов'язані територі- альними особливостями ринків праці. Аналіз виявив існування гендерної нерівності щодо заробітних плат, зокрема, по країні вона зросла на 2,3\%. Найбільш відчутна різниця у рівнях оплати праці у працівників фрінансової сорери, мистецтва, спорту. Серед населення України відсоток жителів з середньодушовим доходом, нижчим прожиткового мінімуму - 29,9\%.

Структура сукупних витрат домогосподарств країни вказує, що 65\% витрачається на харчування та оплату житла й комунальних послуг. Витрати населення на: охорону здоров'я $4,1 \%$, освіту - 1,1\%, відпочинок і культуру 1,6\%. Отже, левова частка витрат здійснюється на відтворення трудового потенціалу і зовсім мізерна на інвестиції у людський капітал.

Нині в суспільстві спостерігається взаємозалежність якості трудового потенціалу і якості життя:

- 3 одного боку, підвищення якості людських ресурсів можливе за умови покращення освіти, охорони здоров'я, житлових умов, умов праці, іншими словами, за рахунок підвищення якості життя в суспільстві;

- $з$ іншого боку, якість життя цілковито залежить від якості трудового потенціалу працівників.

\section{СПИСОК ВИКОРИСТАНИХ ДЖЕРЕЛ:}

1. Булавинець В.М., Заклекта О.І. Нерівність доходів населення в Україні: чинники та сучасний стан. Ефективна економіка. 2017. № 11. URL: http://www.economy.nayka.com.ua

2. Державна служба статистики України. Офіційний сайт. URL: www.ukrstat.gov.ua

\section{REFERENCES:}

1. Bulavynets, V.M., Zaklekta, O.I. (2017) Nerivnist dokhodiv naselennia v Ukraini: chynnyky ta suchasnyi stan [Income inequality in Ukraine: factors and current situation]. Efektyvna ekonomika, 11. Retrieved from: http://www. economy.nayka.com.ua (in Ukrainian)

2. Derzhavna sluzhba statystyky Ukrayiny [State Statistics Service of Ukraine]. Ofitsiynyy sayt. Retrieved from: http://www.ukrstat.gov.ua/ 